\title{
Protective role of integrin-linked kinase against oxidative stress and in maintenance of genomic integrity
}

\author{
Michelle $\operatorname{Im}^{1,2,3}$ and Lina Dagnino ${ }^{1,2,3}$ \\ ${ }^{1}$ Department of Physiology and Pharmacology, The University of Western London, Ontario, Canada \\ ${ }^{2}$ Lawson Health Research Institute, London, Ontario, Canada \\ ${ }^{3}$ Children's Health Research Institute, London, Ontario, Canada \\ Correspondence to: Lina Dagnino, email: Idagnino@uwo.ca
}

Keywords: oxidative stress; epidermis; integrin-linked kinase

Received: September 27, $2017 \quad$ Accepted: January 24, $2018 \quad$ Published: February 07, 2018

Copyright: Im et al. This is an open-access article distributed under the terms of the Creative Commons Attribution License 3.0 (CC BY 3.0), which permits unrestricted use, distribution, and reproduction in any medium, provided the original author and source are credited.

\section{ABSTRACT}

The balance between the production of reactive oxygen species and activation of antioxidant pathways is essential to maintain a normal redox state in all tissues. Oxidative stress caused by excessive oxidant species generation can cause damage to DNA and other macromolecules, affecting cell function and viability. Here we show that integrinlinked kinase (ILK) plays a key role in eliciting a protective response to oxidative damage in epidermal cells. Inactivation of the Ilk gene causes elevated levels of intracellular oxidant species (IOS) and DNA damage in the absence of exogenous oxidative insults. In ILK-deficient cells, excessive IOS production can be prevented through inhibition of NADPH oxidase activity, with a concomitant reduction in DNA damage. Additionally, ILK is necessary for DNA repair processes following UVB-induced damage, as ILK-deficient cells show a significantly impaired ability to remove cyclobutane pyrimidine dimers following irradiation. Thus, ILK is essential to maintain cellular redox balance and, in its absence, epidermal cells become more susceptible to oxidative damage through mechanisms that involve IOS production by NADPH oxidase activity.

\section{INTRODUCTION}

Given its location at the interface between the body and the environment, the epidermis is constantly in direct contact with oxidants, such as atmospheric oxygen, air pollutants including ozone and airborne metal-containing particles, and UV radiation. The epidermis is, in fact, a tissue exposed to high levels of oxidative damage in large part due to the generation of reactive oxygen species (ROS) [1, 2]. Although ROS play important physiological roles in signalling and normal activation of immune responses, excessive ROS production can lead to harmful oxidation of proteins, lipids and DNA [3].

Several protective mechanisms against oxidative damage exist in the epidermis. Cysteine residues in the small proline-rich family of the cornified envelope precursor proteins are readily oxidized by ROS, thereby serving as a shield in the outermost layer of this tissue [4]. In addition, within the living layers of the epidermis, various antioxidant molecules are actively synthesized, including glutathione, $\alpha$-tocopherol and ascorbic acid, as well as a variety of detoxifying enzymes (reviewed in [2]). Elevated oxidative stress resulting from impaired antioxidant mechanisms or excessive ROS production can give rise to a plethora of cutaneous disorders. For example, increased ROS levels are implicated in the pathogenesis of inflammatory diseases such as psoriasis, in atopic dermatitis and development of allergic reactions in the skin, in drug-induced photosensitization and photodamage $[2,5,6]$. Photodamage from UV radiation is a major cause for cellular senescence, age-associated decreases in epidermal function and regeneration, as well as cutaneous tumour development. UV damage promotes initiation and progression of epidermal carcinomas through mechanisms that include ROS-induced metabolic, genetic and epigenetic alterations in keratinocytes. In particular, activation and upregulation of the ROSproducing enzyme NOX1 is a key step in the formation of epidermal squamous cell carcinomas in response to UV radiation [7]. 
Recent studies have demonstrated that appropriate regulation of redox balance is key to the maintenance of epidermal integrity. For example, in the human genetic disease pachyonychia congenita, and in mouse models of this disorder, elevated oxidative stress occurs through mechanisms that involve attenuated nuclear factor erythroid-derived related factor-2 (NRF2) transcriptional activity, with a consequent reduction in the expression of enzymes involved in glutathione synthesis [8]. Similarly, in Kindler syndrome, a familial blistering disease, inactivating mutations in the FERMT1 gene, which encodes Kindlin-1, result in loss of epidermal attachment and integrity, as well as susceptibility to cutaneous squamous cell carcinomas [9]. Kindlin-1-deficient keratinocytes exhibit higher cellular ROS levels and increased UV-induced DNA damage [10].

Integrin-linked kinase is a ubiquitous scaffold protein that also plays key roles in the maintenance of epidermal integrity and barrier function [11-14]. In keratinocytes, ILK modulates microtubule dynamics, development of front-rear polarity, endosomal trafficking, and forward motility [15-19]. ILK associates with the $\beta 1$ integrin adhesome, and epidermis-restricted inactivation of the Ilk gene results in keratinocyte detachment from the underlying basement membrane through mechanisms that include abnormalities in cellular integrin distribution and signalling [20]. Perturbations in integrin-mediated functions can lead to loss of keratinocyte extracellular matrix deposition and defects in matrix attachment [20]. Integrins and their associated proteins play complex roles in the modulation of oxidant species production. For example, integrin engagement cooperates with growth factor signalling in epithelial cells to activate survival pathways through mechanisms that include ROS generation [21]. Conversely, loss of integrin signals can lead to pathologic stimulation of ROS production, metabolic alterations and anoikis [10, 22]. A key unresolved issue is whether ILK is also involved in controlling cellular redox balance and responses to oxidative stress. We now show that ILK is necessary to maintain normal intracellular oxidant species levels (IOS), thereby protecting cells from oxidative damage. We also demonstrate an essential role for ILK in the repair of DNA lesions following UV irradiation.

\section{RESULTS}

\section{ILK deficiency increases keratinocyte susceptibility to apoptosis under serum deprivation conditions}

To investigate whether ILK regulates keratinocyte survival under various conditions, we measured levels of cytoplasmic oligonucleosomes, indicative of apoptosis, in cells isolated from ILK-expressing $\left(\mathrm{ILK}^{+}\right)$or ILK-deficient $\left(\mathrm{ILK}^{\mathrm{KO}}\right.$ ) epidermis. ILK ${ }^{\mathrm{KO}}$ cells cultured under optimal conditions, consisting of growth medium supplemented with fetal bovine serum (FBS), as well as growth and survival factors (HICE-T3, containing hydrocortisone, insulin, cholera toxin, epidermal growth factor and tri-iodothyronine), exhibited similar levels of apoptosis-associated oligonucleosomes to $\mathrm{ILK}^{+}$cells (Figure 1A). However, when $\mathrm{ILK}^{\mathrm{KO}}$ cells were cultured in serum-deficient medium, they showed significantly higher levels of oligonucleosomes than $\mathrm{ILK}^{+}$keratinocytes, irrespective of whether HICE-T3 factors were present or absent in the culture medium. This indicates a greater susceptibility of ILK-deficient keratinocytes to the pro-apoptotic effects of serum deprivation (Figure 1A). Biochemically, ILK ${ }^{\mathrm{KO}}$ keratinocytes also showed increased levels of active, cleaved caspase 3, relative to normal cells, when they were cultured in the absence of serum and/or growth factors (Figure 1B), indicating that the absence of ILK results in activation of intrinsic apoptosis pathways under those stress conditions. Consistent with this notion, increased levels of an 89-kDa cleavage fragment of PARP-1, generated by caspase-mediated proteolysis, were also present in ILK ${ }^{\mathrm{KO}}$ cells (Figure 1C). Significantly, the abundance of phosphorylated Akt was indistinguishable between ILK+ and ILK $^{\mathrm{KO}}$ cells (Figure 1D), suggesting that ILK is dispensable for Akt phosphorylation, and that the PI3-kinase-Akt survival signalling pathway does not likely contribute significantly to the observed differences in the sensitivity to apoptotic stimuli between ILK-expressing and ILK ${ }^{\mathrm{KO}}$ keratinocytes.

\section{Decreased proliferative capacity of ILK ${ }^{\mathrm{KO}}$ keratinocytes}

The abnormalities in ILK $^{\mathrm{KO}}$ keratinocytes in response to apoptotic stimuli prompted us to investigate if these cells also showed defects in proliferative capacity in the presence of mitogens, by measuring BrdU incorporation into DNA. The percentage of BrdU-positive ILK-expressing cells steadily increased from $<5 \%$ to about $40 \%$ by $72 \mathrm{~h}$ following isolation and culture in normal growth medium. This proportion remained steady once the cell population started to proliferate asynchronously, after $96 \mathrm{~h}$ in culture (Figure 2). In contrast, although the proportion of $\mathrm{ILK}^{\mathrm{KO}}$ keratinocytes that showed BrdU incorporation initially increased $24 \mathrm{~h}$ after plating, it failed to increase any further, suggesting that normal responses to mitogenic factors present in the culture medium are impaired in these cells (Figure 2). Of note, loss of ILK results in spreading defects in cultured keratinocytes [23], and impaired cell spreading in these cells is associated with entry into quiescence and activation of differentiation programs involving Notch signaling [24].

The mammalian mitogen-activated protein kinase (MAPK) pathway includes three main arms: p38, JNK and ERK. Multiple stimuli and stressors activate MAP kinases in keratinocytes and other cell types, including growth factors, hypoxia, UV irradiation and oxidative stress [25-27]. Thus, given the defects in responses to mitogens observed in ILK $^{\mathrm{KO}}$ cells, we next examined 
the relationship between loss of ILK and MAP kinase activation. Significantly, levels of active, phospho-p38, phospho-JNK, and phospho-ERK were 2- to 8-fold higher in ILK $^{\mathrm{KO}}$ cells, irrespective of whether the cells were cultured in the presence or absence of growth factors and serum (Figure 3 ). These observations suggest that ILK deficiency does not impair MAP kinase activation per se. However, the alterations in the proliferation profile of ILK-deficient keratinocytes may be influenced, at least in part, by abnormal activation and/or impaired dephosphorylation of these enzymes, in addition to stress stimuli possibly present in these cells.

A

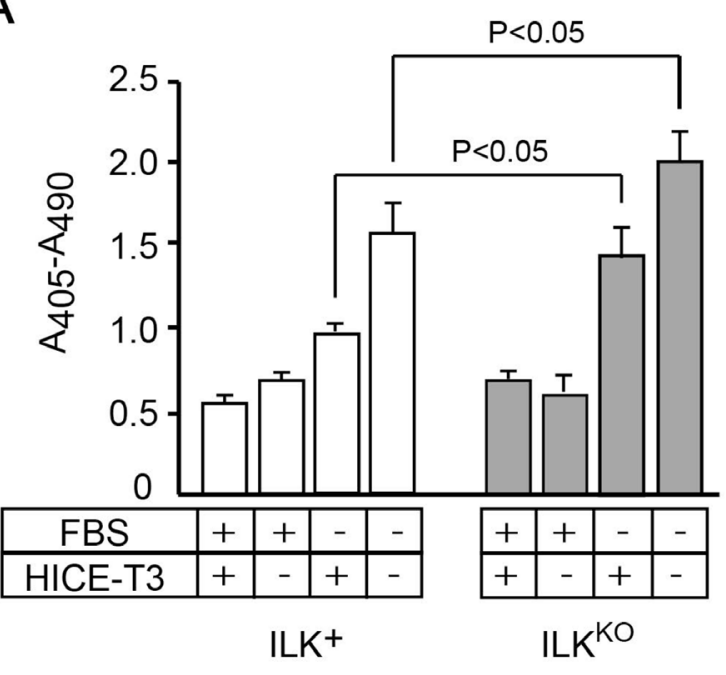

B
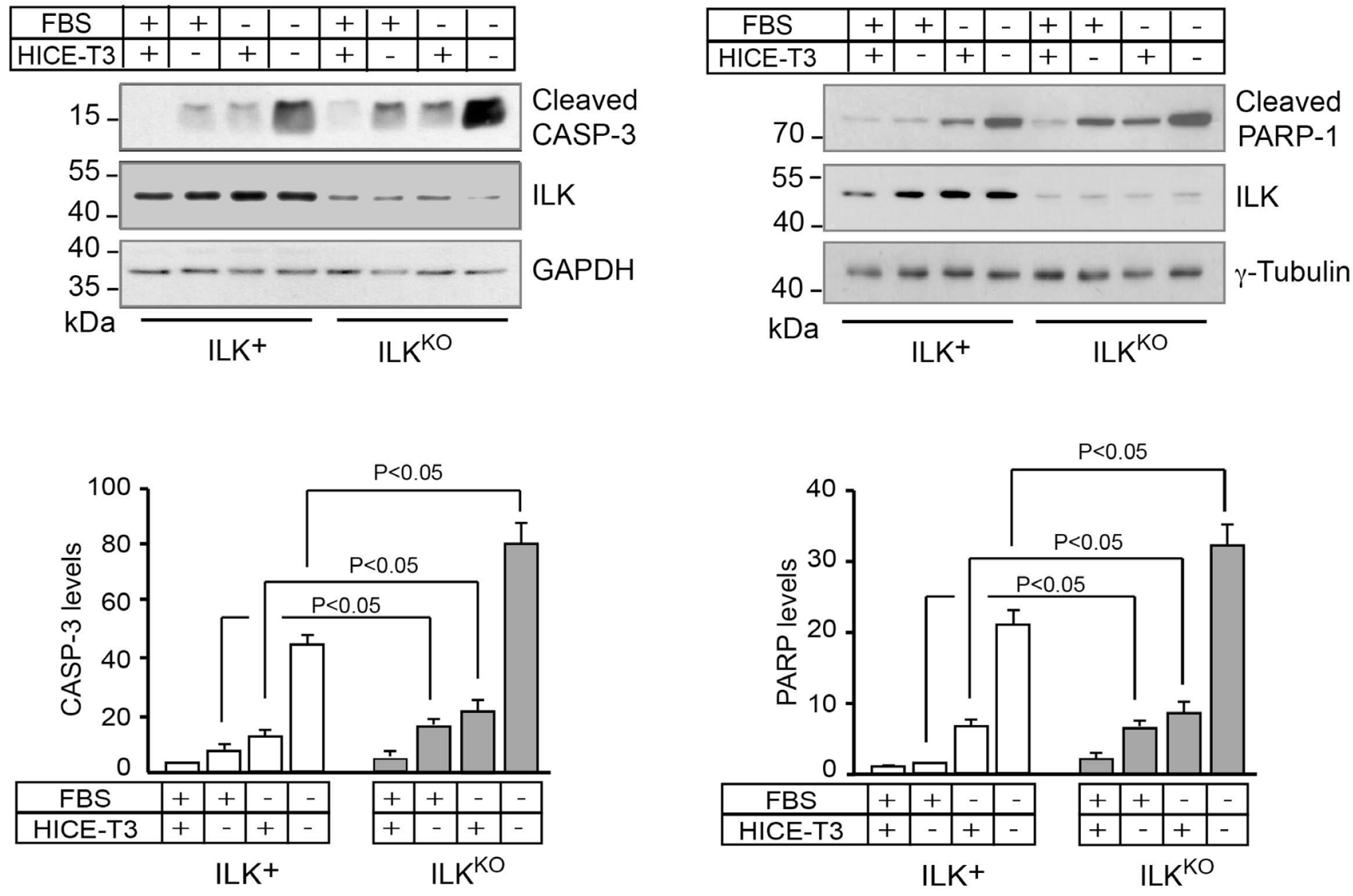

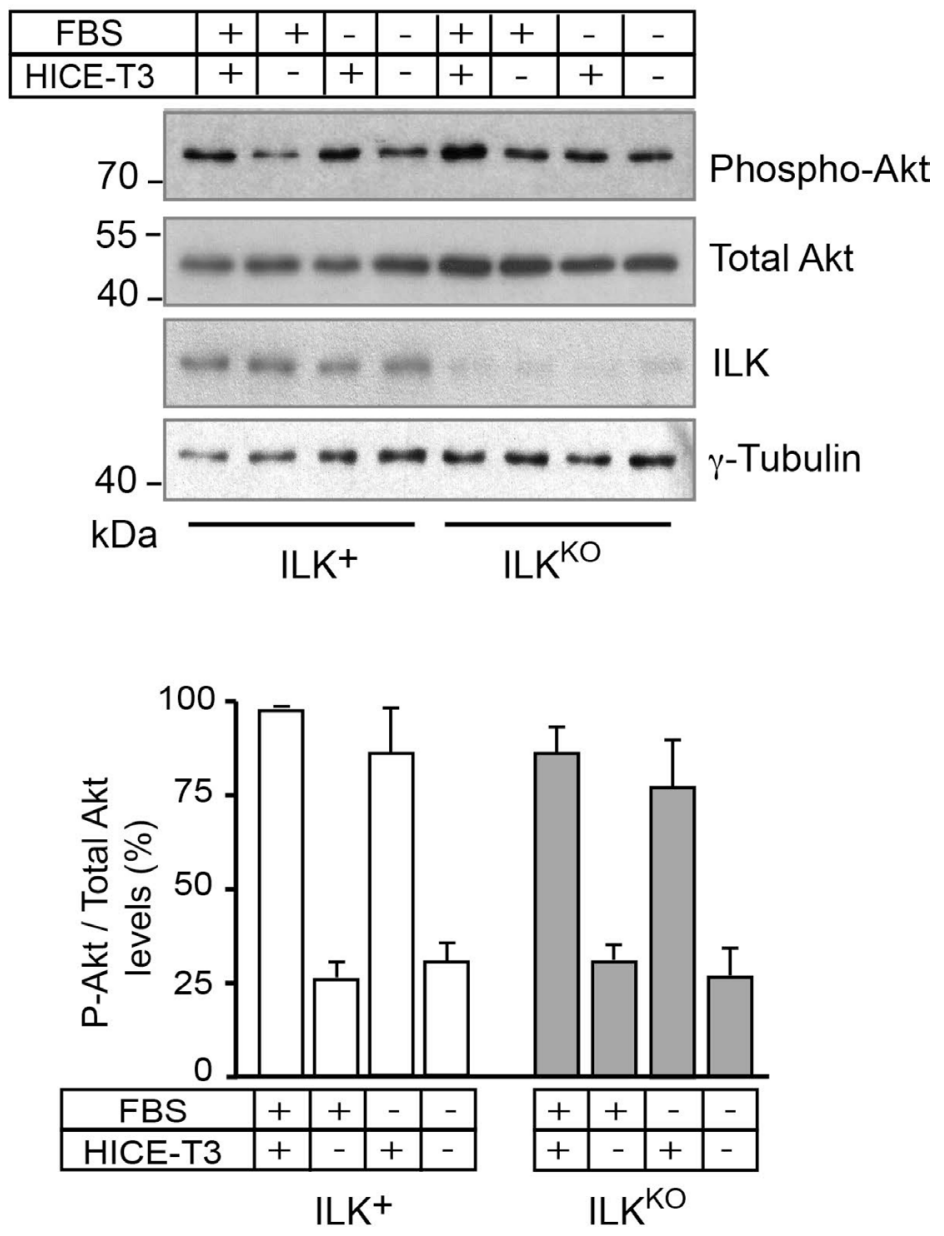

Figure 1: Increased sensitivity of ILK ${ }^{\mathrm{KO}}$ keratinocytes to growth factor deprivation. ILK ${ }^{+}$and ILK ${ }^{\mathrm{KO}} \mathrm{keratinocytes}^{\mathrm{e} e r e}$ cultured in the presence of the indicated additives for $24 \mathrm{~h}$. (A) Cytoplasmic mono- and oligonucleosomes in keratinocyte lysates were quantified using a colorimetric enzyme-linked immunosorbent assay method. The results are expressed as mean absorbance at $405 \mathrm{~nm}$ (reference wavelength $490 \mathrm{~nm}) \pm \operatorname{SEM}(n=7)$. Statistical significance was calculated using ANOVA. (B-D) Cell lysates were analyzed by immunoblot using antibodies against the indicated proteins, and GAPDH or $\gamma$-tubulin served as loading controls. The histograms below each representative immunoblot show normalized densitometric quantification of each protein (mean $\pm \mathrm{SD} ; n=3$ ), and are expressed relative to the abundance in $\mathrm{ILK}^{+}$cells cultured in growth medium with FBS and HICE-T3, which is set to 1.0. Statistical significance was calculated using ANOVA. CASP-3, caspase 3.

\section{Elevated IOS levels in the absence of ILK}

Excessive generation of reactive oxygen species by oxidants or as a result of UV irradiation induces phosphorylation and activation of JNK and ERK in primary epidermal cells [25]. Therefore, we next investigated if cellular IOS levels are altered in ILK ${ }^{\mathrm{KO}}$ keratinocytes by measuring DCFDA fluorescence in intact cells. We observed a $40 \%$ increase in fluorescence values in $\mathrm{ILK}^{\mathrm{KO}}$ cells cultured in normal growth medium, relative to ILK-expressing keratinocytes (Figure 4A). Cellular IOS-associated DCFDA fluorescence remained $40 \%-60 \%$ higher in $\mathrm{ILK}^{\mathrm{KO}}$ cells throughout a $45-\mathrm{min}$ time course of measurements (Figure 4A). Incubation of the cells with $\mathrm{H}_{2} \mathrm{O}_{2}$ resulted in time- and concentration- dependent increases in DCFDA-associated fluorescence in both cell types (Figure 4A, 4B). However, DCFDAassociated fluorescence values in ILK ${ }^{\mathrm{KO}}$ keratinocytes were about 1.5 -fold higher than in ILK ${ }^{+}$cells at all $\mathrm{H}_{2} \mathrm{O}_{2}$ concentrations tested. We also observed that DCFDA fluorescence in ILK ${ }^{\mathrm{KO}}$ cells treated with the glutathione precursor NAC decreased to levels indistinguishable from those in ILK-expressing keratinocytes (Figure 4C). However, upon a 5- or 45-min $\mathrm{H}_{2} \mathrm{O}_{2}$ challenge, NAC treatment was not sufficient to decrease IOS levels in $\mathrm{ILK}^{\mathrm{KO}}$ cells to the same extent observed in $\mathrm{ILK}^{+}$cells (Figure 4C and data not shown). Although the changes in DCFDA fluorescence observed in the presence of $\mathrm{H}_{2} \mathrm{O}_{2}$ likely reflect IOS production from cellular processes, as well as direct formation of hydroxyl radicals from 
chemical breakdown of the exogenously added hydrogen peroxide, collectively, our data are consistent with the notion that the absence of ILK leads to accumulation of IOS and an altered cellular redox state in keratinocytes.

The NADPH oxidase family of transmembrane enzymes, can function as a primary source of oxidant species generation under normal and pathological conditions [28]. This enzyme family is composed of six subunits, which can associate to form an active complex that generates $\mathrm{O}_{2}{ }^{-}$from oxygen and NADPH [28]. There are seven homologues of the catalytic subunit, termed NOX-1 through -5, Duox-1 and Duox-2. Epidermal keratinocytes are known to express NOX-1, NOX-2 and NOX-4, and abnormal NOX-1 activation occurs in keratinocytes in which DNA repair pathways are impaired [29]. To investigate if NOX activity contributed to higher IOS levels in the absence of ILK, we treated keratinocytes with the pan-NOX inhibitor VAS2870. Treatment of normal keratinocytes with VAS2870 decreased DCFDA fluorescence by about $25 \%$. Significantly, the presence
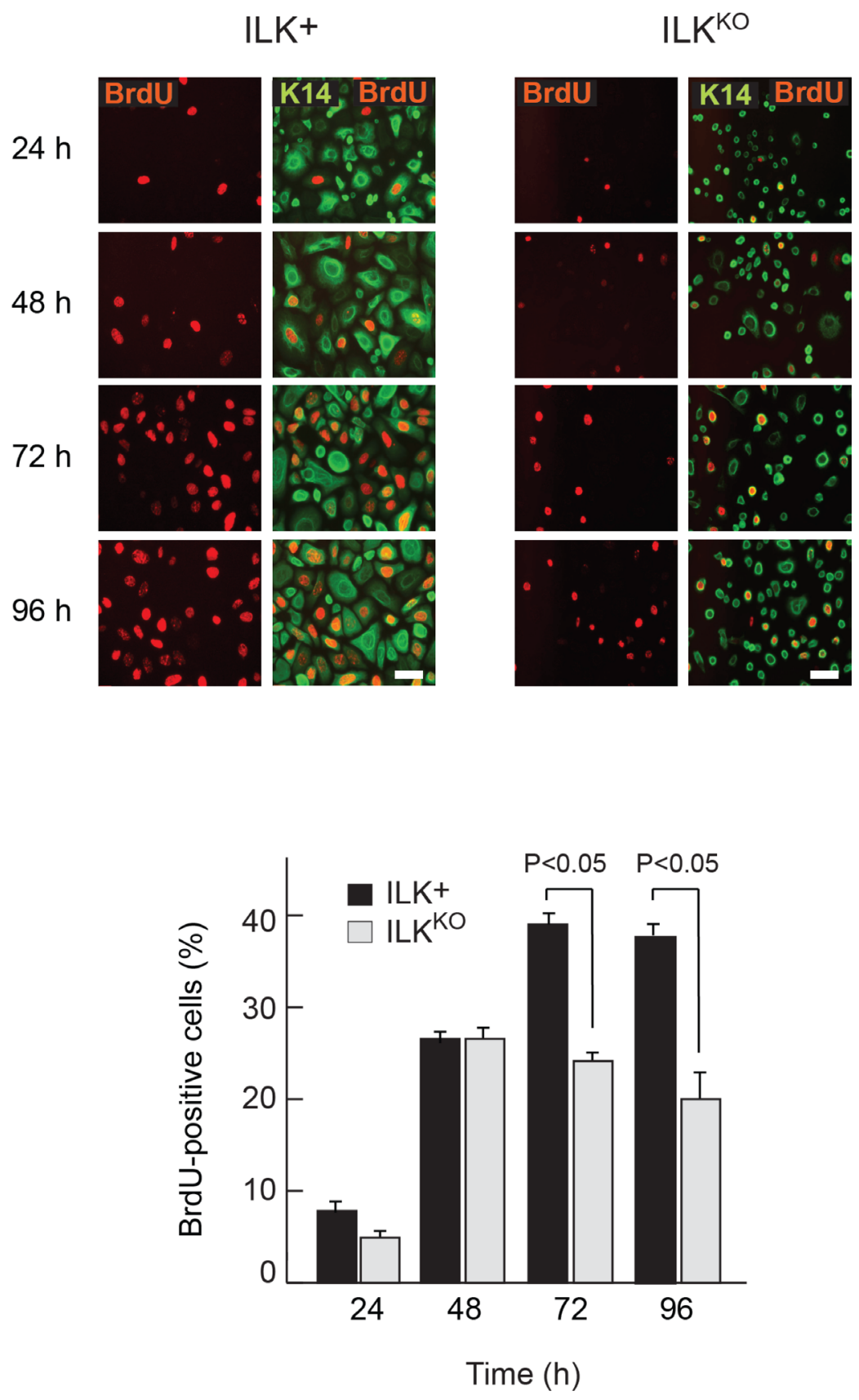

Figure 2: Proliferation defects in ILK ${ }^{\mathrm{KO}}$ keratinocytes. Representative micrographs of keratinocytes incubated in the presence of $10 \mu \mathrm{M}$ BrdU for $2 \mathrm{~h}$ prior to processing for immunofluorescence microscopy using anti-BrdU and anti-keratin 14 (K14) antibodies at the indicated times following isolation and plating. Bar, $60 \mu \mathrm{m}$. The histograms indicate the fraction of BrdU-positive cells of each genotyope, represented as the mean $+\operatorname{SEM}(n=3)$. Statistical significance was calculated using ANOVA. 
of this inhibitor in ILK ${ }^{\mathrm{KO}}$ cultures decreased DCFDA fluorescence about $60 \%$, and to levels indistinguishable to those found in normal keratinocytes (Figure 5). Thus, NADPH oxidase activity likely contributes to the excess IOS observed as a result of $I l k$ gene inactivation.

\section{Increased damage and impaired repair of genomic DNA in the absence of ILK}

Abnormal IOS generation can promote the oxidation of nuclear DNA in keratinocytes and other cell types [30]. DNA lesions produced by reactive oxygen species and other oxidants can include single- and double-strand breaks, and are associated with the formation of phosphorylated histone $\mathrm{H} 2 \mathrm{AX}(\gamma \mathrm{H} 2 \mathrm{AX})$ during the DNA damage response $[31,32]$. Examination of these cells by immunofluorescence microscopy revealed that $0.2 \%-0.5 \%$ of $\mathrm{ILK}^{+}$cells exhibited $\gamma \mathrm{H} 2 \mathrm{AX}$ foci (data not shown). Analysis of lysates prepared from ILK-expressing keratinocytes cultured under optimal growth conditions showed very low levels of $\gamma \mathrm{H} 2 \mathrm{AX}$. Culture of these cells either in serum- or in growth factorfree medium resulted in little, if any, increases in $\gamma \mathrm{H} 2 \mathrm{AX}$, whereas culture in the absence of both serum and growth factors caused a marked increase in $\gamma \mathrm{H} 2 \mathrm{AX}$ abundance (Figure 6A). In stark contrast, the levels of $\gamma \mathrm{H} 2 \mathrm{AX}$ in ILK $^{\mathrm{KO}}$ keratinocytes were consistently 7 - to 10 -fold higher than in normal cells, irrespective of whether they were cultured in optimal, in serum- or in growth factor-deprivation conditions (Figure 6A). To examine the involvement of increased IOS levels in $\mathrm{H} 2 \mathrm{AX}$ phosphorylation, we also measured $\gamma \mathrm{H} 2 \mathrm{AX}$ abundance in cells treated with VAS2870 for $24 \mathrm{~h}$. Although NOX inhibition did not significantly alter the low levels of $\gamma \mathrm{H} 2 \mathrm{AX}$ in ILK-expressing keratinocytes, it reduced them in ILK ${ }^{\mathrm{KO}}$ cells about 7-fold (Figure 6B), indicating a causative link between excessive IOS production via NOX enzymes and activation of DNA damage responses in these cells.

Due to their location on the body surface, epidermal keratinocytes are constantly exposed to damage from UV light and environmental oxygen. Given the increased oxidative stress of ILK ${ }^{\mathrm{KO}}$ cells, we next examined their capacity to repair UV-induced DNA damage. To this end, we subjected the cells to UV irradiation to induce CPD formation in genomic DNA, and measured their ability to repair those lesions as a function of time. ILK-expressing keratinocytes showed maximum CPD levels immediately
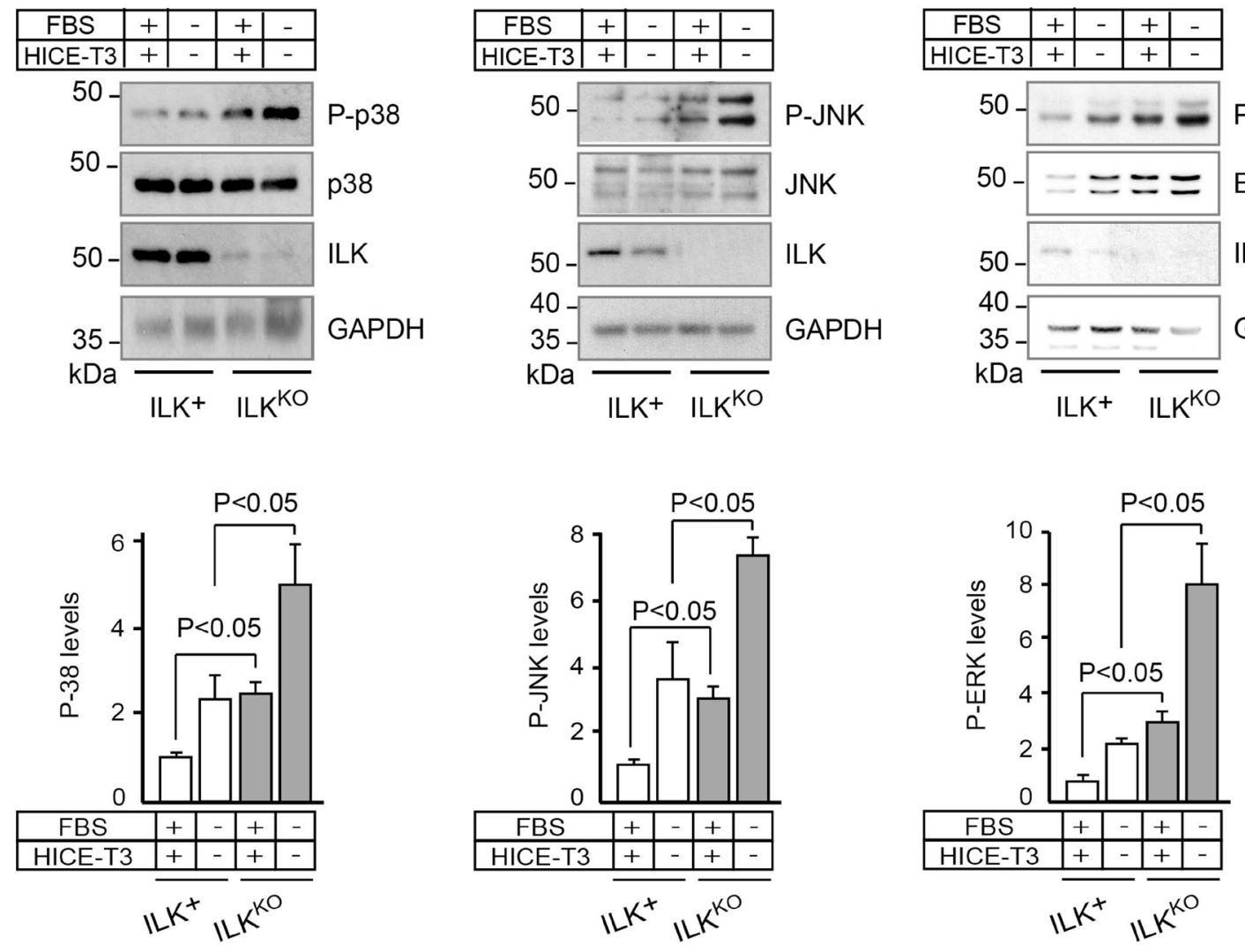

Figure 3: Increased levels of phosphorylated MAP kinases in ILK ${ }^{\mathrm{KO}}$ keratinocytes. Keratinocytes were cultured in the presence or absence of growth additives. After $24 \mathrm{~h}$, cell lysates were prepared and analyzed by immunoblot using antibodies against phosphorylated (P-) or total cellular p38, JNK or ERK; GAPDH served as loading control. The histograms under each representative immunoblot show the densitometric quantification of each phosphorylated protein normalized to the corresponding levels of total protein (mean $\pm \mathrm{SD} ; n=4)$. Statistical significance was calculated using ANOVA. 
A

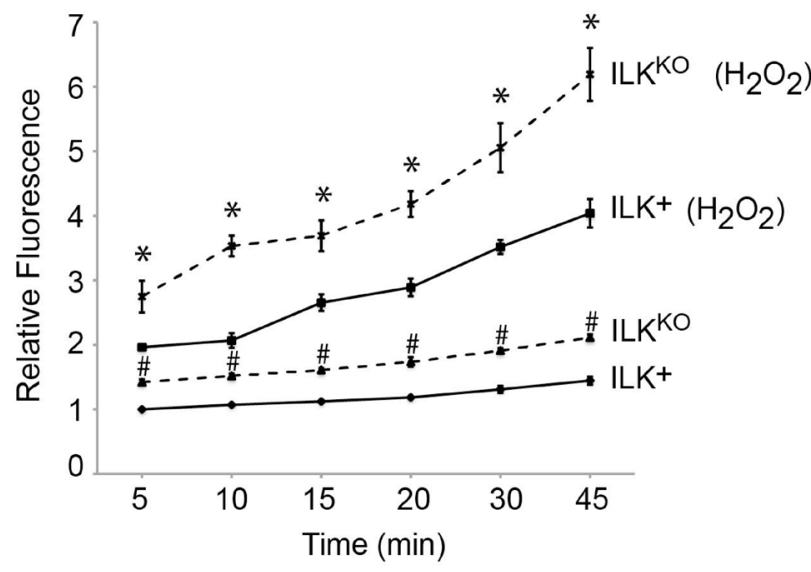

B

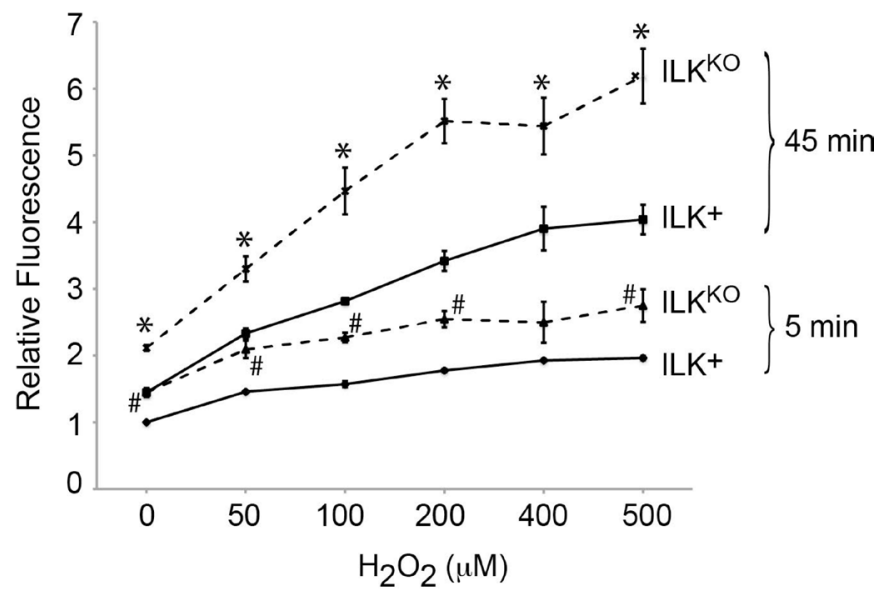

C

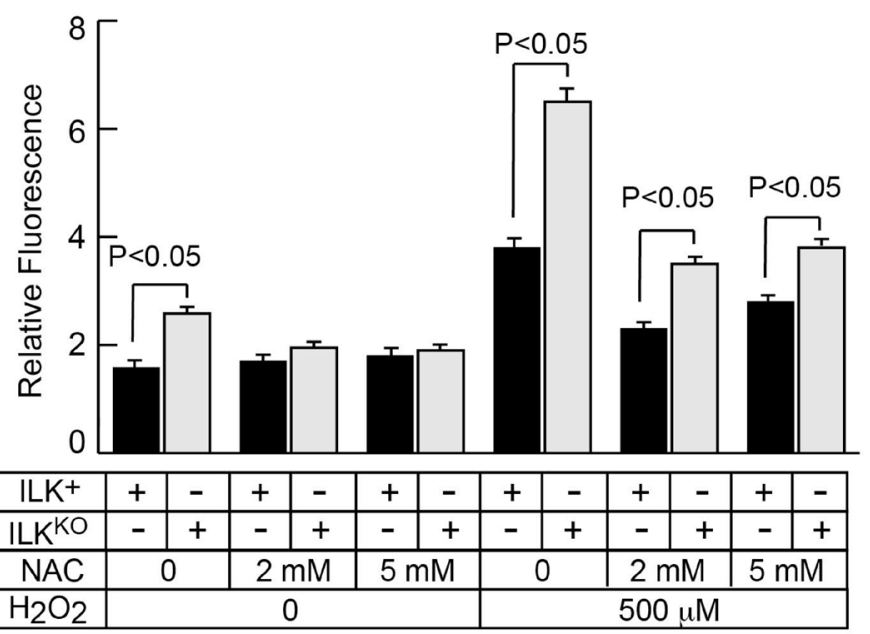

Figure 4: Increased intracellular oxidant species in ILK ${ }^{\mathrm{KO}}$ keratinocytes. Cells were loaded by culture at $37^{\circ} \mathrm{C}$ in the presence of $10 \mu \mathrm{M}$ DCFDA. (A) After DCFDA removal, fluorescence values were determined at the indicated times in cultures incubated with or without $500 \mu \mathrm{M} \mathrm{H}_{2} \mathrm{O}_{2}$, and were normalized for cell number. The results are expressed as fold-change relative to the 5-min normalized fluorescence value in ILK ${ }^{+}$cultures incubated without $\mathrm{H}_{2} \mathrm{O}_{2}$, which is set to 1 . Data are means $\pm \operatorname{SEM}(n=3)$. " and "represent, respectively, $P<0.05$ relative to ILK ${ }^{+}$cells in the absence or presence of $\mathrm{H}_{2} \mathrm{O}_{2}$ at the corresponding time (ANOVA). (B) After DCFDA removal, fluorescence values were determined after 5 or $45 \mathrm{~min}$ in cultures incubated with the indicated $\mathrm{H}_{2} \mathrm{O}_{2}$ concentrations, and were normalized for cell number. The results are expressed as fold-change relative to the 5-min normalized fluorescence value in ILK ${ }^{+}$cultures incubated without $\mathrm{H}_{2} \mathrm{O}_{2}$, which is set to 1 . Data are means $\pm \operatorname{SEM}(n=3)$. \# and "represent, respectively, $P<0.05$ relative to ILK ${ }^{+}$cells in the absence or presence of $\mathrm{H}_{2} \mathrm{O}_{2}$ at the corresponding time (ANOVA). (C) Keratinocytes were incubated with the indicated NAC concentrations for $45 \mathrm{~min}$ and, after NAC removal, were loaded with DCFDA and fluorescence was measured as described in (B). The results are expressed as fold-change in cultures measured after $45 \mathrm{~min}$, relative to the 5 -min normalized fluorescence value in $\mathrm{ILK}^{+}$cultures incubated without $\mathrm{NAC}$ and $\mathrm{H}_{2} \mathrm{O}_{2}$, which is set to 1 . Data are means $\pm \operatorname{SEM}(n=3)$. Statistical significance was calculated using ANOVA. 
after UV irradiation, which decreased by $80 \%$ and $95 \%$, respectively, after $24 \mathrm{~h}$ and $48 \mathrm{~h}$ (Figure 7). UV irradiation of ILK $^{\mathrm{KO}}$ cells produced similar initial CPD levels to those observed in normal keratinocytes. However, CPD abundance in these cells remained unchanged even $48 \mathrm{~h}$ after irradiation, indicating that lack of ILK expression also reduces the DNA repair capacity of the cells.

\section{DISCUSSION}

This study reveals important and novel mechanistic insights into how oxidative stress in keratinocytes is regulated, with specific emphasis on the protective role of ILK against oxidative stress and in maintaining genomic integrity. Our data lead to two major conclusions. First, ILK is involved in protecting cells from growth factor deprivation and modulating processes that maintain proper redox balance. Second, ILK is required for normal genomic integrity and repair after UVB irradiation.

Loss of ILK during embryogenesis also results in abnormal distribution of and signalling through $\beta 1$ integrins, which leads to hair follicle developmental arrest [20]. In the interfollicular epidermis, ILK-deficient keratinocytes exhibit defects in attachment to the basement membrane [33]. In culture, ILK-deficient keratinocytes exhibit defects in cell spreading and fail to form normal focal adhesions [11, 33].
Keratinocytes can respond to the loss of extracellular matrix attachment in different manners. In vivo, undifferentiated keratinocytes in the lowermost basal layer of the epidermis express high levels of $\alpha 6 \beta 4$ and $\alpha \beta 1$ integrins, which contribute to cell attachment to the underlying basement membrane [34]. Targeted inactivation of $I l k$ in mouse epidermis yields abnormalities that closely phenocopy those observed upon inactivation of the Intbl gene [35, 36], suggesting that ILK is likely a critical transducer of a variety of signals received through $\beta 1$ integrins in undifferentiated keratinocytes, including those implicated in responses to growth factor restriction. Although the interruption of ILKmediated survival pathways in keratinocytes cultured under serum and/or growth factor deprivation conditions triggers activation of caspase-dependent apoptosis, this process does not appear to be associated with changes in Akt activation. Stimulation of $\beta 1$ integrins in some cell types causes Akt Ser473 phosphorylation, which can then participate in the activation of cell survival pathways, although contrasting evidence for the role of ILK in Akt regulation has been extensively reported $[37,38]$. Our data show that ILK is dispensable for Akt phosphorylation in undifferentiated keratinocytes. Similarly, in HeLa and MCF-7 epithelial cells, Akt phosphorylation does not depend on ILK, but instead requires RICTOR-mTor complexes [39]. Because inhibition of mTor reduces cell survival in response to UV irradiation in

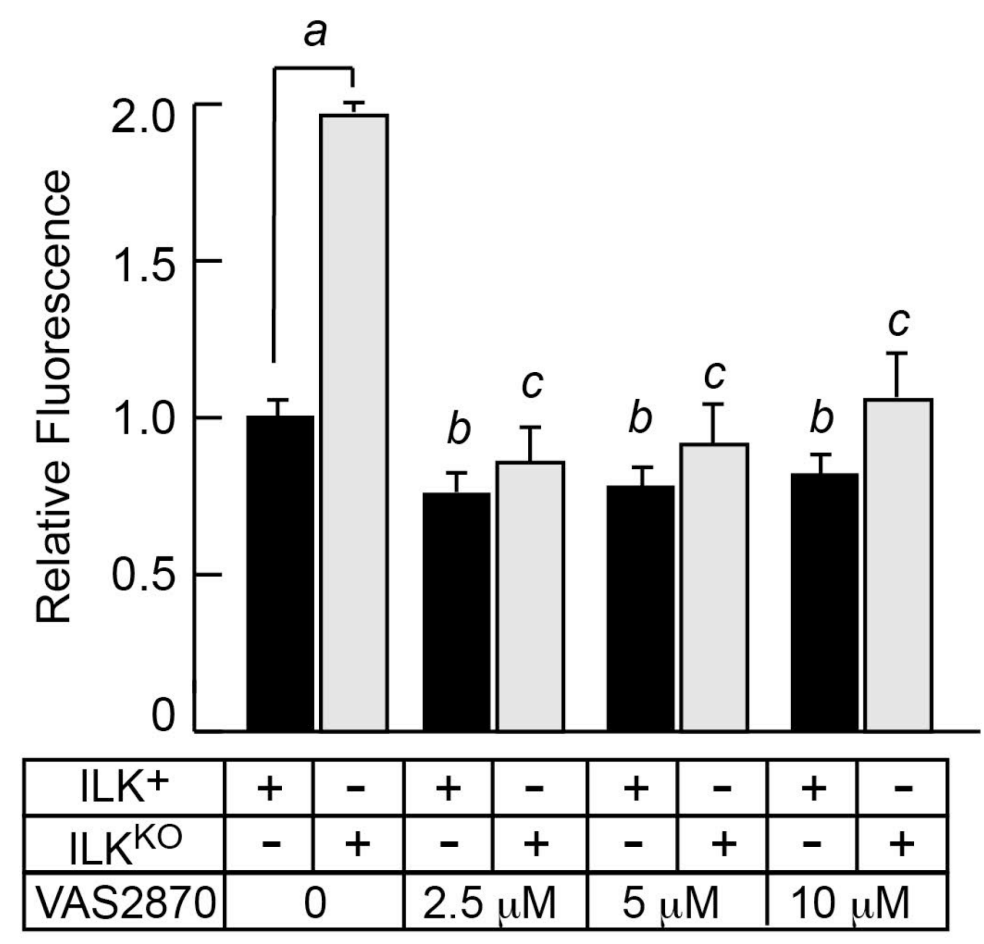

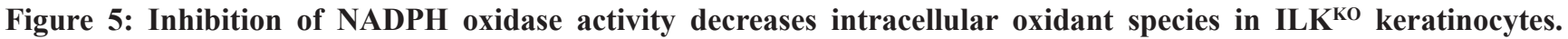
Keratinocytes were cultured in the presence of the indicated concentrations of VAS2870 for $24 \mathrm{~h}$. After removal of the drug, the cells were loaded by incubation at $37^{\circ} \mathrm{C}$ in the presence of $10 \mu \mathrm{M}$ DCFDA. Following DCFDA removal, fluorescence values were determined after $45 \mathrm{~min}$, and were normalized for cell number. The results are expressed as fold-change relative to the normalized fluorescence value in $\mathrm{ILK}^{+}$cultures incubated without VAS2870, which is set to 1 . Data are means + SEM $(n=3)$. ${ }^{\mathrm{a}} P<0.05,{ }^{\mathrm{b}} P<0.05$ relative to ILK ${ }^{+}$cells in the absence of VAS2870, ${ }^{\mathrm{c}} P<0.05$ relative to ILK ${ }^{\mathrm{KO}}$ cells in the absence of VAS2870 (ANOVA). 
A
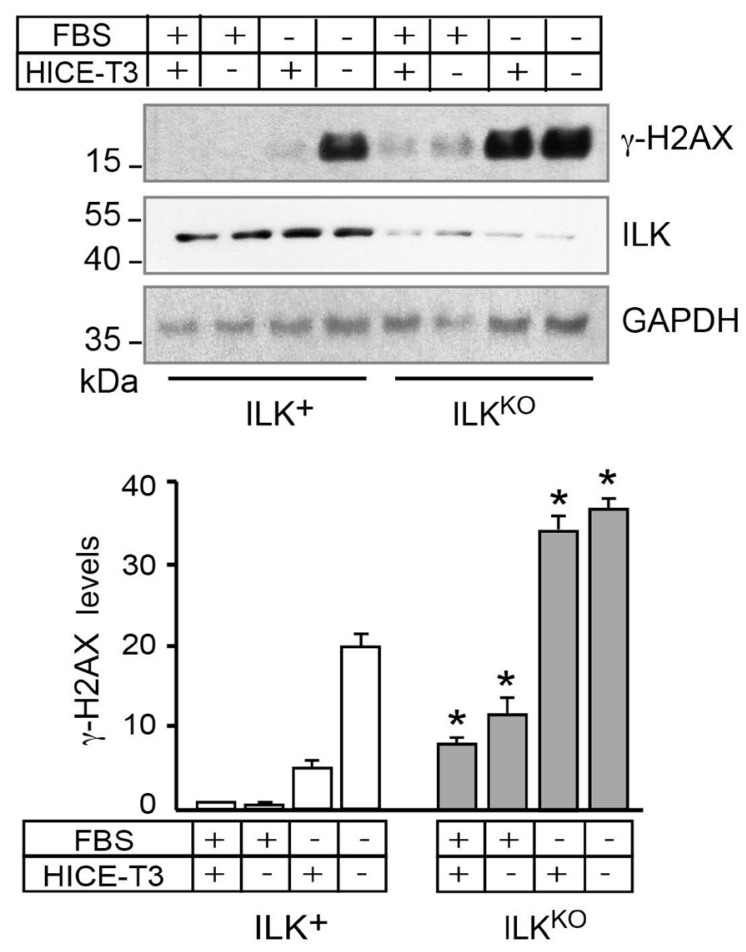

B
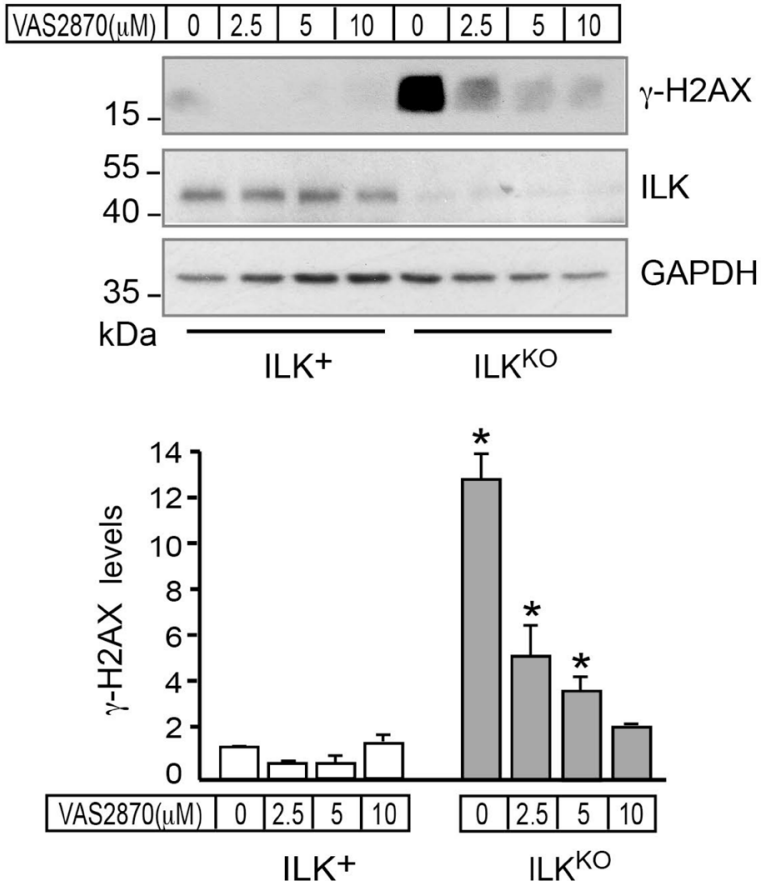

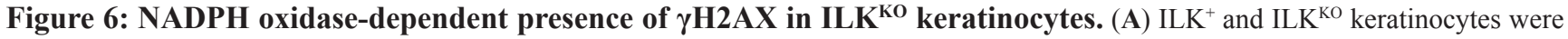
cultured with the indicated growth additives for $24 \mathrm{~h}$. Cell lysates were prepared and $10 \mu \mathrm{g} /$ sample were analyzed by immunoblot using antibodies against the indicated proteins; GAPDH served as loading control. The histograms under the representative immunoblot show $\gamma \mathrm{H} 2 \mathrm{AX}$ densitometric quantification (mean $\pm \mathrm{SD}, n=3$ ), and are expressed relative to levels in ILK-expressing cells cultured in growth medium containing FBS and HICE-T3, set to $1 .{ }^{*} P<0.05$ (ANOVA), relative to $\gamma \mathrm{H} 2 \mathrm{AX}$ levels in ILK ${ }^{+}$cells cultured in the corresponding culture condition. (B) Keratinocytes were cultured in the presence of the indicated concentrations of VAS2870 for $24 \mathrm{~h}$, and the indicated proteins were analyzed as described in (A), using $80 \mu \mathrm{g}$ of protein lysate/sample, to better visualize dose-dependent VAS2870 reductions in $\gamma \mathrm{H} 2 \mathrm{AX}$. The histograms under the representative immunoblot show $\gamma \mathrm{H} 2 \mathrm{AX}$ densitometric quantification (mean $\pm \mathrm{SD}, n=3$ ), and are expressed relative to the level in ILK ${ }^{+}$cells cultured in the absence of drug, which is set to $1 .{ }^{*} P<0.05$ (ANOVA). 
epidermal keratinocytes [40], an important aspect for future research will be to determine whether the reduced viability of ILK-deficient keratinocytes is associated with abnormalities in RICTOR and/or mTor.

Oxidant species are required as signal messengers in many physiological processes. Significantly, interactions between cellular integrins and their surrounding extracellular matrix can also elicit production of IOS [41]. In an apparently paradoxical manner, impaired responses to integrins due to cell detachment can give rise to pathological, elevated levels of IOS production through alterations in several metabolic pathways [41]. For example, a key metabolic alteration in detached mammary epithelial cells is impaired glucose uptake, which triggers a chain of events resulting in reduced levels of ATP and NADPH [22]. Given that the latter serves as a reducing agent and reactive oxygen species scavenger, IOS levels increase under these conditions, although such increases can be prevented by exogenous antioxidants, such as NAC. Similarly, inactivation of $I l k$ in epidermal keratinocytes is accompanied by increases in IOS levels that can be reversed in the presence of NAC, an agent that increases glutathione levels in cultured keratinocytes, affording them protection against UV photodamage [42]. Although glutathione, NADPH levels and glucose uptake in ILKdeficient keratinocytes remain to be measured, we have also observed that lack of ILK in cultured keratinocytes is accompanied by significantly reduced cellular ATP levels (M. Im, S. Sayedyahossein and L. Dagnino, unpublished observations).

A key finding of our study is that inactivation of $I l k$ also leads to increased levels of $\gamma \mathrm{H} 2 \mathrm{AX}$, indicative of DNA lesions and/or activation of the DNA damage response (DDR). The physiological and pathological roles of NOX enzymes in keratinocytes, in which only the isoforms NOX$1,-2$ and -4 have been detected [43], are not fully understood.
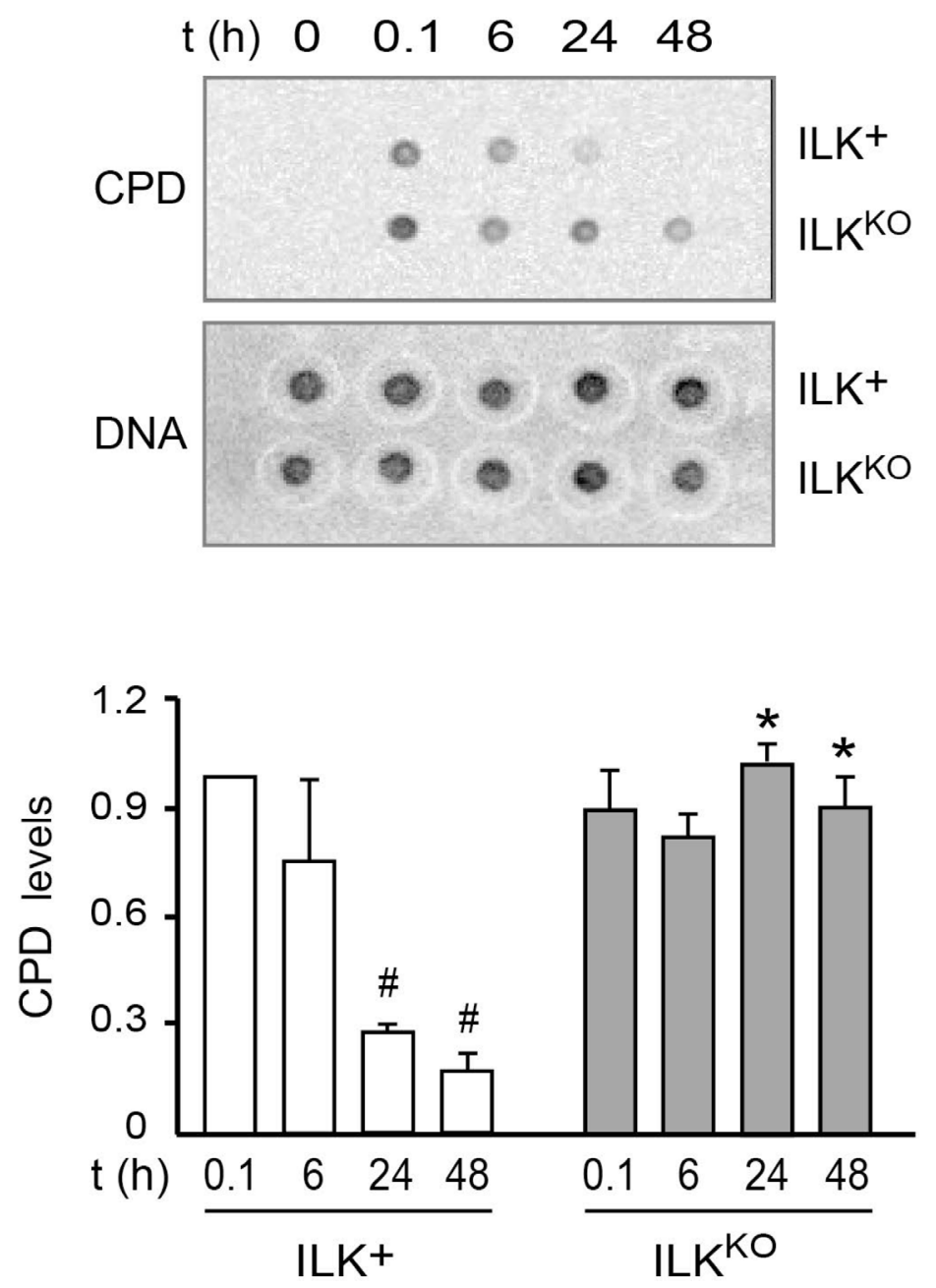

Figure 7: Defective DNA repair following UV-induced damage in ILK ${ }^{\mathrm{KO}}$ keratinocytes. Keratinocytes were subjected to UVB irradiation $\left(50 \mathrm{~J} / \mathrm{m}^{2}\right)$. Genomic DNA was isolated at the indicated times thereafter, and analyzed for the presence of CPD as described in "Materials and Methods". CPD levels were normalized to the amount of double-stranded DNA spotted on a replicate membrane. The histograms under the representative blots show the fraction of normalized CPD signal remaining after 6, 24 and 48 h, relative to CPD levels measured $0.1 \mathrm{~h}$ after irradiation (set to 1 ). The results are expressed as mean $\pm \mathrm{SD}(n=3) .{ }^{\#} P<0.05$ relative to CPD in ILK ${ }^{+}$cells at $t=0.1$; ${ }^{*} P<0.05$ relative to $\mathrm{CPD}$ in $\mathrm{ILK}^{+}$at each corresponding time following UVB irradiation (ANOVA). 
IOS production by NOX-1 in response to growth factors, and possibly $\alpha 3 \beta 1$ integrin stimulation too, requires Tiam1mediated Rac1 activation in keratinocytes [26]. Although ILK is an essential upstream mediator of Racl activation in these cells in response to growth factor- and $\alpha 3 \beta 1$ integrinstimulation [11, 15, 33, 44, 45], the seemingly paradoxical elevation in IOS levels in ILK-deficient keratinocytes cultured in the presence of growth factors suggests that either normal Rac1 activation is dispensable in this process, or that it occurs through ILK-independent pathways. Alternatively, initial supranormal IOS production in ILKdeficient keratinocytes, potentially arising from abnormal integrin- and growth factor-mediated signalling, may lead to DNA and proteome damage, thus initiating a self-sustaining cycle that may involve the activation of one or several molecular pathways. It is well established that DNA lesions trigger stimulation of DDR. Activation of DDR effectors can also induce metabolic IOS production, thus constituting an amplification loop between IOS and the DDR itself [46]. In particular, the DDR component $\gamma \mathrm{H} 2 \mathrm{AX}$ induces IOS increases through mechanisms that involve sequestration of 14-3-3 $\zeta$ and consequent activation of Rac1 and NOX-1 [47]. In keratinocytes, the presence of unrepaired damaged DNA also leads to stimulation of DNA-protein kinase, which, in turn, promotes Akt activation. The latter leads to induction of NOX-1, generation of cytoplasmic IOS and enhanced DNA oxidation, which then causes further IOS generation and sustained macromolecular damage [30]. Given that ILK $^{\mathrm{KO}}$ cells also exhibit defects in proliferation and increased sensitivity to apoptotic stimuli, it is possible that these defects also contribute to the observed changes in IOS and DNA integrity observed. Although it is difficult to accurately determine the extent of such contributions, our observation that inhibition of NADPH oxidases is accompanied by reduction of IOS would suggest that some of the apoptosisrelated events we observed in ILK-deficient keratinocytes might occur downstream from abnormal NOX dependent IOS production.

Double DNA strand breaks are some of the most ominous forms of DNA damage, and the generation of $\gamma \mathrm{H} 2 \mathrm{AX}$ serves to recruit repair factors to protect genomic integrity. Of note, $\gamma \mathrm{H} 2 \mathrm{AX}$ can also serve as a biomarker of other types of DNA lesions and/or DDR activation [32, 48], and studies to address in detail the type of DNA damage or DDR present in ILK ${ }^{\mathrm{KO}}$ cells and the mechanisms involved will be key areas for future research. The constitutively high levels of $\gamma \mathrm{H} 2 \mathrm{AX}$ in ILK-deficient keratinocytes suggest that these cells may also be more susceptible to genomic instability upon oxidative insults, with potential outcomes that include apoptosis, senescence and/or carcinogenic transformation. In support of this notion, we demonstrated that the ability of ILK-deficient cells to repair DNA photolesions is reduced. Additionally, given that ILK $^{\mathrm{KO}}$ cells are more susceptible to be negatively affected by various stressors, as seen with growth factor deprivation, it is possible that these properties may contribute, at least in part, to their reduced ability to remove CPD lesions following UV irradiation. The direct analyses of the excision-repair components in these cells should address these issues in the future. Recently, NOX-1 expression and activity were found to increase as a result of DNA lesions arising from UVB photodamage or from the genetic impairment of DNA repair efficiency, such as during loss of normal XPC function [7, 29]. In addition, blockade of NOX-1 activation in response to UVB irradiation increases DNA nucleotide excision repair, decreasing genomic instability and formation of cutaneous squamous cell carcinomas [7]. Conversely, impaired DNA repair efficiency causes NOX-1 activation, subsequently leading to increased cytoplasmic IOS production, and altered mitochondrial bioenergetics [29]. Significantly, similar to ILK-deficient keratinocytes, inactivation of the Racl gene in these cells results in attenuated DDR responses and increased susceptibility to carcinogenesis following UV irradiation [49]. Given that ILK is required for Racl activation in several processes independent of integrin signalling [45], it will be important to determine whether Rac1 is a downstream ILK effector in DNA repair responses following UV irradiation in epidermal cells.

Under normal conditions, the outermost regions of the skin are supplied by external oxygen, which diffuses from the air to a depth of about $400 \mu \mathrm{m}$ [50]. The non-vascularized epidermis, with an average thickness of 40-70 $\mu \mathrm{m}$ [51], receives its oxygen supply exclusively through atmospheric oxygen. Although accurate measurements of partial oxygen pressure $\left(\mathrm{pO}_{2}\right)$ in the skin are technically challenging, a $\mathrm{pO}_{2}$ of about 120 Torr has been estimated for the skin at a depth of $70 \mu \mathrm{m}$, where the lowermost basal epidermal keratinocyte are found [50]. This value is close to the atmospheric $\mathrm{pO}_{2}$ at sea level of about 160 Torr. Thus, unlike many other tissues in the body, including the innermost regions of the dermis, epidermal keratinocytes are physiologically exposed to near atmospheric $\mathrm{pO}_{2}$ values [50], which closely mirror the conditions of our experiments. Intracellular oxidant species and antioxidant levels determine the redox state in tissues and cells, and the location of epidermal keratinocytes on the body surface results in their constant exposure to IOS-generating external stimuli. Thus, the ability of these cells to regulate their redox state is key for epidermal homeostasis. We have now shown that, in addition to its central roles in epidermal development and physical integrity, ILK is also critical for the maintenance in this tissue of redox equilibrium and proper function of DNA repair pathways in response to UVinduced photodamage.

\section{MATERIALS AND METHODS}

\section{Mouse strains}

The generation and genotyping of mice with epidermis-restricted inactivation of the $I l k$ gene has been 
described [20, 33].All animal experiments were approved by the University of Western Ontario Animal Care Committee (Protocol No. 2015-021), in accordance with regulations and guidelines from the Canadian Council on Animal Care.

\section{Reagents and antibodies}

Cholera toxin (100) and insulin (16634) were from List Biological (Campbell, CA, USA) and Invitrogen (Carlsbad, CA, USA), respectively. Chelex 100 resin was purchased from Biorad (Mississauga, ON, Canada). Rat tail collagen I was from BD Biosciences (Bedford, MA), and 2',7'-dichlorofluorescein diacetate (DCFDA) was from Calbiochem (EMD Millipore; Billerica, MA). VAS2070 (492000) was from EMD Millipore Corporation (Billerica, MA). All other reagents were purchased from Sigma (St. Louis, MO, USA). The primary antibodies used were: Bax (sc-493, Santa Cruz Biotechnology, Santa Cruz, CA), 5'-bromodeoxyuridine (BrdU, G3G4, Developmental Studies Hybridoma Bank, Iowa City, IA), cyclobutane pyrimidine dimers (CPD; Clone TDM2, CAC-NMDND-001, Cosmo Bio International, Tokyo, Japan), doublestrand DNA (dsDNA) (ab27156, Abcam, Cambridge, MA), GAPDH (ADI CSA 335, Enzo Life Sciences, Ann Arbour, MA), ILK (611802, BD Transduction Laboratories, Lexington, KY), $\gamma$-tubulin (T6557, Sigma). The following antibodies were purchased from Cell Signaling Technology (Beverly, MA): Cleaved caspase-3 (9661), cleaved PARP1 (9544), total Akt (9272), phospho-Akt (Thr308, 9275), total p38 (9212), phospho-p38 (Thr180/Tyr182, 4511), $\gamma \mathrm{H} 2 \mathrm{AX}$ (9718), total p42/p44 ERK (9101), phospho-p42/ p44 ERK (Thr202/Tyr185, 4370), total SAPK/JNK (9252), and phospho-SAPK/JNK (Thr183/Tyr185, 4668). Alexa Fluor-conjugated goat anti-mouse IgG, goat anti-rabbit IgG and phalloidin (A12381) were purchased from Molecular Probes/Invitrogen (Eugene, OR).

\section{Keratinocyte isolation and culture}

Keratinocytes were isolated from 3-day-old $I l k^{\text {tm } 1 \text { Star }}$ mice (hereafter termed ILK ${ }^{\mathrm{f} / \mathrm{f}}$ ), with two functional alleles of the Ilk gene [52], from K14Cre; $I l k^{f /+}$ mice (ILKexpressing, with one functional Ilk allele, hereafter termed $\mathrm{ILK}^{+}$) or $\mathrm{K} 14 \mathrm{Cre}$; Ilkff littermates (ILK-deficient, hereafter termed $\mathrm{ILK}^{\mathrm{KO}}$ ), as described $[44,53,54]$. Keratinocytes were seeded either onto cell culture plates or on acidwashed glass coverslips coated with poly-L-lysine (1 mg/ $\mathrm{ml})$ and rat-tail collagen type $\mathrm{I}\left(5 \mu \mathrm{g} / \mathrm{cm}^{2}\right)$. All experiments were conducted with keratinocytes cultured 48-72 h after isolation, at $\leq 80 \%$ confluence. In experiments using $\mathrm{H}_{2} \mathrm{O}_{2}$, the latter was diluted in growth medium immediately before addition to cells. N-acetylcysteine (NAC) stock solutions $(125 \mathrm{mM})$ were prepared in phosphate-buffered saline (PBS), and the $\mathrm{pH}$ was adjusted to 7.4 prior to addition to cultures. All experiments were conducted 3-5 times with triplicate samples and independent cell isolates.

\section{Analysis of cell proliferation and apoptosis}

To determine BrdU incorporation into DNA, cells $\left(1 \times 10^{5}\right.$ cells $\left./ \mathrm{cm}^{2}\right)$ were incubated for $2 \mathrm{~h}$ in the presence of $10 \mu \mathrm{M}$ BrdU. The cells were fixed in freshly diluted $4 \%$ paraformaldehyde (PFA, $40 \mathrm{~min}, 4^{\circ} \mathrm{C}$ ) and permeabilized in $0.1 \%$ Triton-X 100 . Nuclear DNA was denatured by incubation in $2 \mathrm{M} \mathrm{HCl}\left(20 \mathrm{~min}, 22^{\circ} \mathrm{C}\right)$. The cells were probed with anti-BrdU antibodies, and the fraction of cells exhibiting BrdU immunoreactivity was determined from immunofluorescence micrographs as described [55]. Apoptosis was measured by colorimetric quantification of cytoplasmic mono- and oligonucleosomes, using a Cell Death ELISA kit (Roche Applied Science), as described [36].

\section{Immunoblot analysis}

The preparation of cell lysates and their analysis by immunoblot has been described $[16,56]$. For analysis of phosphorylated proteins, cell lysates were prepared using Phosphosafe extraction buffer (EMD Millipore) supplemented with protease inhibitors [57]. Protein levels in immunoblots were determined by densitometric analysis, using Image $\mathrm{J}(\mathrm{NIH})$, or from images acquired on a VersaDoc imaging system equipped with Quantity One software for quantification (BioRad Laboratories, Hercules, CA).

\section{Immunofluorescence microscopy}

Following a rinse with PBS, keratinocyte specimens were permeabilized and fixed by incubation with PBS containing $0.1 \%$ Triton X-100 and freshly-diluted 4\% PFA for $20 \mathrm{~min}\left(22^{\circ} \mathrm{C}\right)[55,58]$. The cells were rinsed twice with PBS and blocked overnight $\left(4^{\circ} \mathrm{C}\right)$ with PBS containing $5 \%$ nonfat dry milk and 5\% goat serum. After three PBS washes, the cells were incubated with primary antibody for $1 \mathrm{~h}\left(22^{\circ} \mathrm{C}\right)$. After three 20-min PBS washes, the cells were probed with AlexaFluor-conjugated secondary antibody, at $22^{\circ} \mathrm{C}$ for $1 \mathrm{~h}$. After removal of the secondary antibody, the cells were rinsed twice, incubated with Hoechst 33342 $(10 \mu \mathrm{g} / \mathrm{ml})$ in PBS for $5 \mathrm{~min}$ at $22^{\circ} \mathrm{C}$, rinsed five times, and mounted in Immu-Mount medium (Thermo Scientific, Pittsburgh, PA). Immunofluorescence micrographs were obtained with a Leica DMIRBE fluorescence microscope (Leica Microsystems, Wetzlar, Germany) equipped with an Orca-ER digital camera (Hamamatsu Photonics, Hamamatsu, Japan), using Volocity 4.3.2 software. At least 100 individual cells of each genotype were scored in each experiment, and the experiments were repeated with 4 independent cell isolates. 


\section{Measurement of intracellular oxidant species}

To evaluate IOS production, keratinocytes seeded in 96-well plates $\left(1 \times 10^{5}\right.$ cells $\left./ 0.32 \mathrm{~cm}^{2}\right)$ were cultured in the presence of $10 \mu \mathrm{M}$ DCFDA at $37^{\circ} \mathrm{C}$ for $45 \mathrm{~min}$, protected from light. Following a PBS wash and addition of PBS containing $8 \%$ FBS, fluorescence was measured at timed intervals thereafter using a microplate reader (490 $\mathrm{nm}$ excitation and $535 \mathrm{~nm}$ emission) and Softmax Pro V. 5 software. Replicate samples were used to determine the number of cells in the samples, and fluorescence values were normalized to cell number. As indicated in some experiments, cells were incubated in the presence of $2 \mathrm{mM}$ or $5 \mathrm{mM} \mathrm{NAC}$ for $45 \mathrm{~min}$ at $37^{\circ} \mathrm{C}$ prior to DCFDA addition. To measure IOS generation in response to hydrogen peroxide, DCFDA-treated keratinocytes were incubated in the presence of $\mathrm{H}_{2} \mathrm{O}_{2}$, and DFCDA-associated fluorescence was measured at timed intervals thereafter.

\section{UV irradiation and CPD measurements}

The levels of DNA-associated CPD were determined as previously described [59]. Keratinocytes plated in 6-cm culture dishes at a density of 3-3.5 $\times$ $10^{6}$ cells/dish were rinsed with PBS and irradiated with $50 \mathrm{~mJ} / \mathrm{m}^{2}$ UVB light using a UVM-28 EL series lamp (302 nm, UVP, Upland, CA). The cells were cultured and genomic DNA was isolated at timed intervals following UVB irradiation, using a DNeasy Blood and Tissue Kit (69506, Qiagen, Germantown, MD). DNA (200 ng) was then diluted in TE buffer (10 mM Tris-HCl, $1 \mathrm{mM}$ EDTA, $\mathrm{pH}$ 7.5), denatured by heating to $100^{\circ} \mathrm{C}$ and spotted onto Hybond-N+ membranes (Amersham/GE Health Care Life Sciences, Mississauga, Canada). The membranes were baked $\left(80^{\circ} \mathrm{C}, 1 \mathrm{~h}\right)$. The DNA was denatured by incubation in $0.4 \mathrm{M} \mathrm{NaOH}\left(20 \mathrm{~min}, 22^{\circ} \mathrm{C}\right)$. The membranes were rinsed with PBS containing $0.2 \%$ Tween-20, and probed with anti-CPD antibodies, as described for the immunoblot analyses. DNA loading was normalized probing replicate membranes spotted with non-denatured DNA, using antibodies against double-strand DNA.

\section{Statistical analysis}

Statistical analyses were conducted on experiments of 3-5 biological replicates obtained from independent cell isolates, and analyzed by one-way analysis of variance (ANOVA) with Bonferroni post-hoc test, or two-tailed paired $t$-test, as appropriate, using GraphPad Prism version 5. Significance was set at $P<0.05$.

\section{Abbreviations}

ANOVA: analysis of variance; BrdU: 5-bromo2'-deoxyuridine; CPD: cyclobutane pyrimidine dimers; DCFDA, 2',7'-dichlorofluorescein diacetate; DDR:
DNA damage response; dsDNA: double-strand DNA; FBS: fetal bovine serum; GAPDH: glyceraldehyde 3-phosphodehydrogenase; ILK: integrin-linked kinase; IOS: intracellular oxidant species; MAPK: mitogenactivated protein kinase; PBS: phosphate-buffered saline.

\section{ACKNOWLEDGMENTS}

The authors thank Dr. R. Cumming and the members of the Dagnino laboratory for critical reading on this manuscript. The expert technical assistance of T. Irvine is gratefully acknowledged. LD supervised this study, designed research, analyzed the data and wrote the paper. MI conducted all the experiments and analyzed the data.

\section{CONFLICTS OF INTEREST}

The authors have no conflicts of interest to declare.

\section{GRANT SUPPORT}

This work was funded by grants to LD from the Canadian Institutes of Health Research (FRN 110303) and the Cancer Research Society.

\section{REFERENCES}

1. Magnani ND, Muresan XM, Belmonte G, Cervellati F, Sticozzi C, Pecorelli A, Miracco C, Marchini T, Evelson P, Valacchi G. Skin Damage Mechanisms Related to Airborne Particulate Matter Exposure. Toxicological sciences. 2016; 149:227-236.

2. Bickers DR, Athar M. Oxidative stress in the pathogenesis of skin disease. J Invest Dermatol. 2006; 126:2565-2575.

3. Deshmukh P, Unni S, Krishnappa G, Padmanabhan B. The Keap1-Nrf2 pathway: promising therapeutic target to counteract ROS-mediated damage in cancers and neurodegenerative diseases. Biophysical reviews. 2017; 9:41-56.

4. Vermeij WP, Alia A, Backendorf C. ROS quenching potential of the epidermal cornified cell envelope. J Invest Dermatol. 2011; 131:1435-1441.

5. Briganti S, Picardo M. Antioxidant activity, lipid peroxidation and skin diseases. What's new. Journal of the European Academy of Dermatology and Venereology. 2003; 17:663-669.

6. Okayama Y. Oxidative stress in allergic and inflammatory skin diseases. Current drug targets Inflammation and allergy. 2005; 4:517-519.

7. Raad H, Serrano-Sanchez M, Harfouche G, Mahfouf W, Bortolotto D, Bergeron V, Kasraian Z, Dousset L, Hosseini M, Taieb A, Rezvani HR. NADPH Oxidase-1 Plays a Key Role in Keratinocyte Responses to UV Radiation and UVB-Induced Skin Carcinogenesis. J Invest Dermatol. 2017; 137:1311-1321. 
8. Kerns ML, Hakim JM, Lu RG, Guo Y, Berroth A, Kaspar RL, Coulombe PA. Oxidative stress and dysfunctional NRF2 underlie pachyonychia congenita phenotypes. J Clin Invest. 2016; 126:2356-2366.

9. Lai-Cheong JE, Parsons M, McGrath JA. The role of kindlins in cell biology and relevance to human disease. Int J Biochem Cell Biol. 2010; 42:595-603.

10. Emmert H, Patel H, Brunton VG. Kindlin-1 protects cells from oxidative damage through activation of ERK signalling. Free Radic Biol Med. 2017; 108:896-903.

11. Lorenz K, Grashoff C, Torka R, Sakai T, Langbein L, Bloch W, Aumalley M, Fassler R. Integrin-linked kinase is required for epidermal and hair follicle morphogenesis. $\mathrm{J}$ Cell Biol. 2007; 177:501-513.

12. Ivanova IA, Nakrieko KA, Dagnino L. Phosphorylation by p38 MAP kinase is required for E2F1 degradation and keratinocyte differentiation. Oncogene. 2009; 28:52-63.

13. Judah D, Rudkouskaya A, Wilson R, Carter DE, Dagnino L. Multiple roles of integrin-linked kinase in epidermal development, maturation and pigmentation revealed by molecular profiling. PLoS One. 2012; 7:e36704.

14. Sayedyahossein S, Rudkouskaya A, Leclerc V, Dagnino L. Integrin-Linked Kinase Is Indispensable for Keratinocyte Differentiation and Epidermal Barrier Function. J Invest Dermatol. 2016; 136:425-435.

15. Ho E, Dagnino L. Epidermal growth factor induction of front-rear polarity and migration in keratinocytes is mediated by integrin-linked kinase and ELMO2. Mol Biol Cell. 2012; 23:492-502.

16. Ho E, Irvine T, Vilk GJ, Lajoie G, Ravichandran KS, D’Souza SJ, Dagnino L. Integrin-linked Kinase Interactions with ELMO2 Modulate Cell Polarity. Mol Biol Cell. 2009; 20:3033-3043.

17. Wickstrom SA, Lange A, Hess MW, Polleux J, Spatz JP, Kruger M, Pfaller K, Lambacher A, Bloch W, Mann M, Huber LA, Fassler R. Integrin-linked kinase controls microtubule dynamics required for plasma membrane targeting of caveolae. Dev Cell. 2010; 19:574-588.

18. Wickstrom SA, Lange A, Montanez E, Fassler R. The ILK/ $\mathrm{PINCH} /$ parvin complex: the kinase is dead, long live the pseudokinase! EMBO J. 2010; 29:281-291.

19. Ho E, Ivanova IA, Dagnino L. Integrin-linked kinase and ELMO2 modulate recycling endosomes in keratinocytes. Biochim Biophys Acta. 2016; 1863:2892-2904.

20. Rudkouskaya A, Welch I, Dagnino L. ILK modulates epithelial polarity and matrix formation in hair follicles. Mol Biol Cell. 2014; 25:620-632.

21. Paoli P, Giannoni E, Chiarugi P. Anoikis molecular pathways and its role in cancer progression. Biochim Biophys Acta. 2013; 1833:3481-3498.

22. Schafer ZT, Grassian AR, Song L, Jiang Z, Gerhart-Hines Z, Irie HY, Gao S, Puigserver P, Brugge JS. Antioxidant and oncogene rescue of metabolic defects caused by loss of matrix attachment. Nature. 2009; 461:109-113.
23. Nakrieko KA, Vespa A, Mason D, Irvine TS, D’Souza SJ, Dagnino L. Modulation of integrin-linked kinase nucleocytoplasmic shuttling by ILKAP and CRM1. Cell Cycle. 2008; 7:2157-2166.

24. Totaro A, Castellan M, Battilana G, Zanconato F, Azzolin L, Giulitti S, Cordenonsi M, Piccolo S. YAP/TAZ link cell mechanics to Notch signalling to control epidermal stem cell fate. Nat Commun. 2017; 8:15206.

25. Moriyama M, Moriyama H, Uda J, Kubo H, Nakajima $Y$, Goto A, Morita T, Hayakawa T. BNIP3 upregulation via stimulation of ERK and JNK activity is required for the protection of keratinocytes from UVB-induced apoptosis. Cell Death Dis. 2017; 8:e2576.

26. Rygiel TP, Mertens AE, Strumane K, van der Kammen R, Collard JG. The Rac activator Tiam1 prevents keratinocyte apoptosis by controlling ROS-mediated ERK phosphorylation. J Cell Sci. 2008; 121:1183-1192.

27. D’Souza SJ, Vespa A, Murkherjee S, Maher A, Pajak A, Dagnino L. E2F-1 is essential for normal epidermal wound repair. J Biol Chem. 2002; 277:10626-10632.

28. Altenhofer S, Kleikers PW, Radermacher KA, Scheurer P, Rob Hermans JJ, Schiffers P, Ho H, Wingler K, Schmidt HH. The NOX toolbox: validating the role of NADPH oxidases in physiology and disease. Cell Mol Life Sci. 2012; 69:2327-2343.

29. Rezvani HR, Rossignol R, Ali N, Benard G, Tang X, Yang HS, Jouary T, de Verneuil H, Taieb A, Kim AL, Mazurier F. XPC silencing in normal human keratinocytes triggers metabolic alterations through NOX-1 activationmediated reactive oxygen species. Biochim Biophys Acta. 2011; 1807:609-619.

30. Rezvani HR, Kim AL, Rossignol R, Ali N, Daly M, Mahfouf W, Bellance N, Taieb A, de Verneuil H, Mazurier F, Bickers DR. XPC silencing in normal human keratinocytes triggers metabolic alterations that drive the formation of squamous cell carcinomas. J Clin Invest. 2011; 121:195-211.

31. Xu B, Wang W, Guo H, Sun Z, Wei Z, Zhang X, Liu Z, Tischfield JA, Gong Y, Shao C. Oxidative stress preferentially induces a subtype of micronuclei and mediates the genomic instability caused by p53 dysfunction. Mutat Res. 2014; 770:1-8.

32. Cleaver JE, Feeney L, Revet I. Phosphorylated H2Ax is not an unambiguous marker for DNA double-strand breaks. Cell Cycle. 2011; 10:3223-3224.

33. Nakrieko KA, Welch I, Dupuis H, Bryce D, Pajak A, St Arnaud R, Dedhar S, D'Souza SJ, Dagnino L. Impaired hair follicle morphogenesis and polarized keratinocyte movement upon conditional inactivation of integrinlinked kinase in the epidermis. Mol Biol Cell. 2008; 19:1462-1473.

34. Watt FM. Role of integrins in regulating epidermal adhesion, growth and differentiation. EMBO J. 2002; 21:3919-3926. 
35. Raghavan S, Bauer C, Mundschan G, Li Q, Fuchs E. Conditional ablation of betal integrin in skin. Severe defects in epidermal proliferation, basement membrane formation, and hair follicle invagination. J Cell Bio. 2000; 150:1149-1160.

36. Nakrieko KA, Rudkouskaya A, Irvine TS, D'Souza SJ, Dagnino L. Targeted inactivation of integrin-linked kinase in hair follicle stem cells reveals an important modulatory role in skin repair after injury. Mol Biol Cell. 2011; 22:2532-2540.

37. Delcommenne M, Tan C, Gray V, Rue L, Woodgett J, Dedhar S. Phosphoinositide-3-OH kinase-dependent regulation of glycogen synthase kinase 3 and protein kinase B/AKT by the integrin linked kinase. Proc Natl Acad Sci U S A. 1998; 95:11211-11216.

38. Grashoff C, Aszodi A, Sakai T, Hunziker EB, Fassler R. Integrin-linked kinase regulates chondrocyte shape and proliferation. EMBO Rep. 2003; 4:432-438.

39. Riaz A, Zeller KS, Johansson S. Receptor-specific mechanisms regulate phosphorylation of AKT at Ser473: role of RICTOR in beta1 integrin-mediated cell survival. PLoS One. 2012; 7:e32081.

40. Carr TD, DiGiovanni J, Lynch CJ, Shantz LM. Inhibition of mTOR suppresses UVB-induced keratinocyte proliferation and survival. Cancer Prev Res (Phila). 2012; 5:1394-1404.

41. Eble JA, de Rezende FF. Redox-relevant aspects of the extracellular matrix and its cellular contacts via integrins. Antioxidants \& redox signaling. 2014; 20:1977-1993.

42. Steenvoorden DP, Beijersbergen van Henegouwen GM. Cysteine derivatives protect against UV-induced reactive intermediates in human keratinocytes: the role of glutathione synthesis. Photochem Photobiol. 1997; 66:665-671.

43. Hosseini M, Mahfouf W, Serrano-Sanchez M, Raad H, Harfouche G, Bonneu M, Claverol S, Mazurier F, Rossignol R, Taieb A, Rezvani HR. Premature skin aging features rescued by inhibition of NADPH oxidase activity in XPC-deficient mice. J Invest Dermatol. 2015; 135:1108-1118.

44. Sayedyahossein S, Nini L, Irvine TS, Dagnino L. Essential role of integrin-linked kinase in regulation of phagocytosis in keratinocytes. FASEB J. 2012; 26:4218-4229.

45. Jackson BC, Ivanova IA, Dagnino L. An ELMO2-RhoGILK network modulates microtubule dynamics. Mol Biol Cell. 2015; 26:2712-2725.

46. Caputo F, Vegliante R, Ghibelli L. Redox modulation of the DNA damage response. Biochemical pharmacology. 2012; 84:1292-1306.

47. Kang MA, So EY, Simons AL, Spitz DR, Ouchi T. DNA damage induces reactive oxygen species generation through the H2AX-Nox1/Rac1 pathway. Cell Death Dis. 2012; 3:e249.

48. Cleaver JE. gammaH2Ax: biomarker of damage or functional participant in DNA repair "all that glitters is not gold!”. Photochem Photobiol. 2011; 87:1230-1239.

49. Deshmukh J, Pofahl R, Haase I. Epidermal Rac1 regulates the DNA damage response and protects from UV-lightinduced keratinocyte apoptosis and skin carcinogenesis. Cell Death Dis. 2017; 8:e2664.

50. Stucker M, Struk A, Altmeyer P, Herde M, Baumgartl H, Lubbers DW. The cutaneous uptake of atmospheric oxygen contributes significantly to the oxygen supply of human dermis and epidermis. The Journal of physiology. 2002; 538:985-994.

51. Whitton JT, Everall JD. The thickness of the epidermis. Br J Dermatol. 1973; 89:467-476.

52. Terpstra L, Prud'homme J, Arabian A, Takeda S, Karsenty G, Dedhar S, St-Arnaud R. Reduced chondrocyte proliferation and chondrodysplasia in mice lacking the integrin-linked kinase in chondrocytes. J Cell Biol. 2003; 162:139-148.

53. Sayedyahossein S, Xu SX, Rudkouskaya A, McGavin MJ, McCormick JK, Dagnino L. Staphylococcus aureus keratinocyte invasion is mediated by integrin-linked kinase and Rac1. FASEB J. 2015; 29:711-723.

54. Dagnino L, Ho E, Chang WY. Expression and analysis of exogenous proteins in epidermal cells. Methods Mol Biol. 2010; 585:93-105.

55. Ivanova IA, Dagnino L. Activation of p38- and CRM1dependent nuclear export promotes E2F1 degradation during keratinocyte differentiation. Oncogene. 2007; 26:1147-1154.

56. Ivanova IA, Vespa A, Dagnino L. A novel mechanism of E2F1 regulation via nucleocytoplasmic shuttling: determinants of nuclear import and export. Cell Cycle. 2007; 6:2186-2195.

57. Vi L, Boo S, Sayedyahossein S, Singh RK, McLean S, Di Guglielmo GM, Dagnino L. Modulation of Type II TGFbeta Receptor Degradation by Integrin-Linked Kinase. J Invest Dermatol. 2015; 135:885-894.

58. Vespa A, D’Souza SJ, Dagnino L. A novel role for integrinlinked kinase in epithelial sheet morphogenesis. Mol Biol Cell. 2005; 16:4084-4095.

59. Singh RK, Dagnino L. E2F1 interactions with hHR23A inhibit its degradation and promote DNA repair. Oncotarget. 2016; 7:26275-26292. https://doi.org/10.18632/oncotarget.8362. 